\title{
Evaluation of Heat Treatment Parameters' Effect on Some Physical and Mechanical Properties of Poplar Wood with Multi-criteria Decision Making Techniques
}

\begin{abstract}
Alperen Kaymakci, ${ }^{\text {a,* }}$ and Bahadır Çağrı Bayram ${ }^{\mathrm{b}}$
Effects of the heat treatment parameters were evaluated relative to some physical and mechanical properties of poplar wood (Populus alba L.) with use of two of the prominent multi criteria decision-making (MCDM) techniques: Entropy and The Technique for Order Preference by Similarity to Ideal Solution (TOPSIS). To meet this objective, the test samples were heat-treated at $120,150,180$, and $210{ }^{\circ} \mathrm{C}$ for 2 and $4 \mathrm{~h}$ in a laboratoryscale oven. With increasing temperature and duration, the shrinkage and swelling ratios of heat-treated samples were improved. However, the bending strength, modulus of elasticity, and compression strength generally decreased with increasing process temperature and duration. According to (MCDM) analyses, thermal modification definitely improved the physical properties of wood up to a point. Bending strength was found to be the most important determinant of heat treatment success. The other determinants were identified as swelling, compression strength, shrinkage, and modulus of elasticity, respectively. Also, the best results were obtained at $120^{\circ} \mathrm{C}$ for $2 \mathrm{~h}$. In general, heat treatment above $150{ }^{\circ} \mathrm{C}$ or $4 \mathrm{~h}$ is not recommended.
\end{abstract}

Keywords: Heat treatment; Physical properties; TOPSIS; Decision making; Entropy weight method

Contact information: a: Department of Wood Mechanics and Technology, Forestry Faculty, Kastamonu University, 37150, Kastamonu, Turkey; b: Department of Forest Industry Machinery and Business Administration, Kastamonu University, 37150, Kastamonu, Turkey;

*Corresponding author: akaymakci@kastamonu.edu.tr

\section{INTRODUCTION}

The increasing demand for wood-based products has caused serious reductions in global forest resources. Therefore, the most efficient use of wood raw material is of great importance. Considering the primary (timber, veneer, plywood, particleboard, fiberboard) and secondary (parquet, woodwork, furniture, etc.) usage of wood raw material, the demand for wood products is unlimited (Göker and Dündar 1999; Kabakci and Kesik 2020).

Although a wide variety of methods have been implemented to meet the wood raw material need, the most effective method is undoubtedly the prevention of loss of wood raw material and taking various saving measures. It is possible to specify the measures as to meet the wood need by import, to increase wood raw material production, and to focus on growing fast growing tree species through industrial plantations. For this purpose, Eucalyptus camaldulensis, Eucalyptus grandis, Pinus pinaster, Pinus radiata, Pinus taeda, Pseudotsuga menziesii, Pinus brutia, Pinus nigra, Fraxinus excelsior, and Populus (Populus nigra, Populus x euramericana and Populus deltoides) species are being evaluated as fast-growing tree species (Birler 2009).

Due to its many advantageous features, wood has a wide range of uses. Wood material is a very important raw material especially for the building industry because of its 
easy processing, enabling surface treatment, different pattern and color alternatives, heat, sound and electrical insulation, and acoustic properties (Aydin 2019). Despite these advantages, wood material also has some negative properties. Examples include the easy destruction of wood material by microorganisms and insects, low dimensional stability, and the fact that color and surface appearance are not homogeneous. In order to eliminate these disadvantages, modifications can be carried out on wood material using various methods. All methods for protecting wood against biotic and abiotic factors are generally classified as wood modification methods. These methods include chemical, surface, impregnation, and thermal modification.

Thermal modification allows the chemical structure of polymer compounds in the cell wall to change permanently (Boonstra 2008). This method improves wood properties without addition of any chemical substance. Within the scope of thermal modification, many types of wood, different temperatures, heating rate and durations have been studied to determine the optimum process conditions (Syrjänen and Kangas 2000; Zaman et al. 2000; Militz 2002; Mazela et al. 2003; Esteves et al. 2007; Kesik et al. 2017; Durmaz et al. 2019).

The physical and mechanical properties of the thermally modified wood change permanently due to the thermal degradation of hemicellulose, which starts at approximately at $150{ }^{\circ} \mathrm{C}$ and continues with increasing temperature. Temperature is the most important factor in heat treatment. In addition, the type of wood directly affects the heat treatment durations, process atmosphere, and moisture content and temperature distribution (Yildiz 2002). The success of the heat treatment depends on several factors. Heat treatment can be completely successful only with the application of these factors at optimum values. This process is a decision-making problem that consists of various and related criteria. The best thermal modification variation and its parameters can be determined with multi-criteria decision making (MCDM) methods.

There are many MCDM techniques, and they diverge in the complexity of use and the need of introducing further subjective variables such as weights (Bakhoum and Brown 2013). TOPSIS and entropy methods were selected because they are appropriate for the goal, and a hybrid approach consisting of these was applied. Entropy was used to evaluate the weights of criteria that will be used at TOPSIS to rank the alternatives.

TOPSIS is one of the well-known MCDM methods (Ouyang et al. 2014), which was first developed by Hwang and Yoon in 1981. Today, TOPSIS has been employed as a decision-making tool for numerous areas (Abidin et al. 2016). Each method has its own advantages. Entropy is robust, versatile, and efficient, and it can cope with the deficiencies of subjective weighting methods (Bakhoum and Brown 2013; Wang et al. 2017). TOPSIS is practical and logically represents the rational human selection by considering both the best and worst attributes of the alternatives at the same time; both the computation and the presentation of the results are simple (Abidin et al. 2016; Long et al. 2019). It is suitable for cases with many attributes and alternatives, as well as being practical for objectives with quantitative data (Sayareh and Alizmini 2014).

There are many published studies of effects of process conditions such as temperature and duration on the results of thermal modification of wood. However, the use of multi-criteria decision-making methods in determining the effect of optimum process parameters on the thermal modification of wood have not been studied extensively. Accordingly, this study focused on the evaluation of heat treatment parameters' effects on some physical and mechanical properties of wood with multi-criteria decision making techniques. Two well-known MCDM techniques were used: entropy and TOPSIS. A hybrid approach of these methods was implemented. 


\section{EXPERIMENTAL}

\section{Materials}

Poplar (Populus alba L.) wood specimens were obtained from forest product companies in İstanbul, Turkey. The mean age of the trees was 23 years, and diameter at breast height was $35 \mathrm{~cm}$. Defect-free test samples were sized in dimensions of $20 \mathrm{~mm} \times 20$ $\mathrm{mm} \times 30 \mathrm{~mm}$ and $20 \mathrm{~mm} \times 20 \mathrm{~mm} \times 300 \mathrm{~mm}$. Heat treatment was carried out in a laboratory-scale oven at $120,150,180$, and $210{ }^{\circ} \mathrm{C}$ for 2 and $4 \mathrm{~h}$. Samples were kept in a conditioning chamber until $12 \%$ moisture content was reached.

\section{Methods}

Heat treatments were conducted in a temperature-controlled small heating unit. Three different temperatures $\left(120,150,180\right.$, and $\left.210^{\circ} \mathrm{C}\right)$ and two durations $(2$ and $4 \mathrm{~h}$ ) were applied to specimens under atmospheric pressure $\left(\mathrm{O}_{2}\right)$. After heat treatment, treated and untreated samples were conditioned at $20 \pm 2{ }^{\circ} \mathrm{C}$ and $65 \pm 5 \%$ relative humidity $(\mathrm{RH})$. Prior to the tests, the dimensions were measured by digital calliper (resolution: $0.001 \mathrm{~mm}$ ) and their weights were recorded by digital weight scale (accuracy: $0.001 \mathrm{~g}$ ).

Tests of bending strength, compression strength, modulus of elasticity, shrinkage, and swelling were carried out based on related Turkish Standards (TS) 2474 (1976), TS 2478 (1976), TS 2495 (1976), TS 4083 (1976) and TS 4084 (1982), respectively

After obtaining experiment results (see Tables 1 and 2), entropy and TOPSIS methods were employed. To be able to use the mentioned methods, a decision matrix is needed. A decision matrix is composed of rows and columns that allow the evaluation of the alternatives relative to multiple decision criteria (Chang 2015). In the matrix (Table 3), the criteria are listed in the first row, while the alternatives are listed in the first column. Whilst the entropy method was used to calculate the importance level (weights) of experiment criteria, TOPSIS method was adopted to rank the experiment samples.

Entropy is one of the objective weighting methods (Zhou et al. 2016). It is based on Shannon Entropy, developed by Shannon (1948). Entropy is a simple yet effective technique for determining the weights of evaluation criteria in a MCDM problem (Ouyang et al. 2014). It presents no serious modelling difficulties and makes decision making more accurate and certain (Song et al. 2017). The steps of entropy method can be summarized simply as: 1) Construct a decision matrix, 2) Normalize the decision matrix, 3) Calculate the entropy value for each evaluation criterion, 4) Compute the weight vector for all evaluation criteria.

The executed calculations in the Results and Discussion are based on the algorithm given in Zhou et al. (2016). According to evaluation indexes that are the maximal index or minimal index, the standardization of the indexes is calculated and shown. After calculation of the weights with Entropy, TOPSIS method was used for ranking the alternatives. The steps of TOPSIS method can be listed simply as: 1) Construct a decision matrix, 2) Normalize the decision matrix, 3) Determine the weighted decision matrix, 4) Determine ideal and negative-ideal solutions, 5) Calculate the distance, 6) Calculate the relative degree of approximation, 7) Ranking (The executed calculations in results and discussion are based on the algorithm given in $\mathrm{Li}$ et al. 2011; for details see therein).

\section{RESULTS AND DISCUSSION}

\section{Physical Properties}

Table 1 shows the changes in the shrinkage and swelling ratios of poplar wood at 
varying treatment temperature and durations. The heat treatment process diminished the magnitudes of dimensional changes of poplar wood, according to the conditions employed in the shrinkage and swelling tests. The lowest shrinkage ratio obtained was after wood heat treatment at $210{ }^{\circ} \mathrm{C}$ for $4 \mathrm{~h}(9.65 \%)$, where the total decrease compared to the control was $28.72 \%$. Similarly, the lowest swelling ratio resulted was after treatment at $210{ }^{\circ} \mathrm{C}$ for $4 \mathrm{~h}(10.25 \%)$; total decrease compared with the control was $34.16 \%$.

Table 1. Shrinkage and Swelling Ratios of Heat Treated Poplar Samples

\begin{tabular}{|c|c|c|c|c|c|c|}
\hline \multirow[t]{2}{*}{ ID } & \multirow{2}{*}{\multicolumn{2}{|c|}{ Samples }} & \multicolumn{2}{|c|}{ Shrinkage (\%) } & \multicolumn{2}{|c|}{ Swelling (\%) } \\
\hline & & & Mean & SD & Mean & SD \\
\hline $\mathrm{O}$ & \multicolumn{2}{|c|}{ Control } & 13.54 & 0.047 & 15.57 & 0.017 \\
\hline $\bar{A}$ & \multirow{2}{*}{$120^{\circ} \mathrm{C}$} & $2 \mathrm{~h}$ & 12.87 & 0.019 & 14.80 & 0.027 \\
\hline$B$ & & $4 \mathrm{~h}$ & 12.58 & 0.019 & 14.47 & 0.023 \\
\hline $\mathrm{C}$ & \multirow{2}{*}{$150^{\circ} \mathrm{C}$} & $2 \mathrm{~h}$ & 12.44 & 0.011 & 14.30 & 0.015 \\
\hline $\mathrm{D}$ & & $4 \mathrm{~h}$ & 12.13 & 0.018 & 13.95 & 0.013 \\
\hline$E$ & \multirow{2}{*}{$180^{\circ} \mathrm{C}$} & $2 \mathrm{~h}$ & 11.94 & 0.014 & 13.73 & 0.031 \\
\hline $\mathrm{F}$ & & $4 \mathrm{~h}$ & 11.21 & 0.016 & 12.90 & 0.017 \\
\hline$G$ & \multirow{2}{*}{$210^{\circ} \mathrm{C}$} & $2 \mathrm{~h}$ & 10.87 & 0.021 & 11.76 & 0.028 \\
\hline $\mathrm{H}$ & & $4 \mathrm{~h}$ & 9.65 & 0.032 & 10.25 & 0.025 \\
\hline
\end{tabular}

These findings are consistent with other studies; for example, Korkut and Guller (2008) stated that the swelling rates of red bud maple (Acer trautvetteri Medw.) wood decreased with increasing treatment temperature and duration. In addition, Yang et al. (2016) found similar results with the Japanese cedar (Dryptomeria japonica) wood. They found that the dimensional stability of the Japanese cedar wood was improved in response to increasing temperatures and long periods. The researchers attributed this to the reduction in the amounts of hydroxyl groups of wood during heat treatment. Improvement in dimensional stability properties can be explained by the heat degradation rate and loss of subsequent heat treatments. The improvement in dimensional stability is mainly due to the depolymerization of wood polymers (Kotilainen et al. 2000). The change in dimensional stability is due to the breakdown of hemicelluloses, which are less heat resistant than cellulose and lignin. Change or loss of hemicelluloses is important in the dimensional stability properties of wood heated at high temperatures (Hillis 1984).

\section{Mechanical Properties}

Table 2 displays results of compression strength, bending strength, and MOE for the control and heat-treated wood samples for combinations of temperature and duration. The heat treatment process generally decreased the compression strength, bending strength, and modulus of elasticity (MOE) of poplar wood. The lowest compressive strength determined was at $210^{\circ} \mathrm{C}$ for $4 \mathrm{~h}$; the total decrease was $21.63 \%$. Similarly, the lowest bending strength and MOE was at $210{ }^{\circ} \mathrm{C}$ for $4 \mathrm{~h}$; the total decrease compared with control samples was 46.27 and $28.10 \%$, respectively. 
Table 2. Compression Strength, Bending Strength, and Modulus of Elasticity of Heat Treated Poplar Samples

\begin{tabular}{|c|c|c|c|c|c|c|c|c|}
\hline \multirow[t]{2}{*}{ ID } & \multirow{2}{*}{\multicolumn{2}{|c|}{ Samples }} & \multicolumn{2}{|c|}{$\begin{array}{l}\text { Compression } \\
\text { Strength } \\
\text { (MPa) }\end{array}$} & \multicolumn{2}{|c|}{$\begin{array}{c}\text { Bending } \\
\text { Strength } \\
\text { (MPa) }\end{array}$} & \multicolumn{2}{|c|}{$\begin{array}{c}\text { Modulus of } \\
\text { Elasticity (MOE) } \\
(\mathrm{MPa})\end{array}$} \\
\hline & & & Mean & SD & Mean & SD & Mean & SD \\
\hline $\mathrm{O}$ & \multicolumn{2}{|c|}{ Control } & 54.17 & 4.31 & 69.00 & 11.7 & 10231.0 & 1477.43 \\
\hline A & \multirow{2}{*}{$120^{\circ} \mathrm{C}$} & $2 \mathrm{~h}$ & 59.10 & 5.54 & 66.47 & 13.74 & 9659.8 & 967.88 \\
\hline B & & $4 \mathrm{~h}$ & 61.97 & 4.73 & 62.28 & 8.18 & 9333.4 & 774.43 \\
\hline$C$ & \multirow{2}{*}{$150^{\circ} \mathrm{C}$} & $2 \mathrm{~h}$ & 59.55 & 5.08 & 62.29 & 5.93 & 9040.4 & 374.72 \\
\hline $\mathrm{D}$ & & $4 \mathrm{~h}$ & 59.26 & 5.62 & 60.74 & 11.74 & 8763.8 & 501.68 \\
\hline$E$ & \multirow{2}{*}{$180^{\circ} \mathrm{C}$} & $2 \mathrm{~h}$ & 58.11 & 5.58 & 54.62 & 8.01 & 8745.4 & 621.93 \\
\hline $\mathrm{F}$ & & $4 \mathrm{~h}$ & 57.62 & 3.98 & 52.56 & 4.83 & 8695.9 & 302.65 \\
\hline $\bar{G}$ & \multirow{2}{*}{$210^{\circ} \mathrm{C}$} & $2 \mathrm{~h}$ & 50.74 & 6.73 & 41.99 & 8.98 & 7587.9 & 741.88 \\
\hline $\mathrm{H}$ & & $4 \mathrm{~h}$ & 42.45 & 11.29 & 37.07 & 10.05 & 7355.6 & 888.94 \\
\hline
\end{tabular}

The primary reason for the loss of mechanical strength is the degradation of hemicelluloses. Hemicellulose losses play a key role in the mechanical strength properties of wood heated at high temperatures (Hillis 1984; Gündüz et al. 2009). Esteves and Pereira (2009) reported that the modulus of elasticity (MOE) increases for moderate heat treatments and decreases for more severe heat treatments. The decreases in the mechanical properties can be explained by the rate of thermal degradation and losses in or changes of substance after heat treatments. Percin et al. (2016) studied the effect of heat treatment on some physical and mechanical properties of beech wood. The higher temperature and duration of heat treatment clearly decreased bending strength and modulus of elasticity in bending. Kamdem et al. (2002) reported that bending strength values of the heat-treated samples showed a declining trend as the treatment temperature and duration were increased. The loss of strength may be attributed to embrittlement of fibers.

Table 3. Decision Matrix

\begin{tabular}{|c|c|c|c|c|c|}
\hline & $\begin{array}{c}\text { Compression } \\
\text { Strength } \\
\left(\mathbf{N} / \mathbf{m m}^{\mathbf{2}}\right)\end{array}$ & $\begin{array}{c}\text { Bending } \\
\text { Strength } \\
\left(\mathbf{N} / \mathbf{m m}^{\mathbf{2}}\right)\end{array}$ & $\begin{array}{c}\text { Modulus of } \\
\text { Elasticity (MOE) } \\
\left(\mathbf{N} / \mathbf{m m}^{\mathbf{2}}\right)\end{array}$ & $\begin{array}{c}\text { Shrinkage } \\
(\%)\end{array}$ & $\begin{array}{c}\text { Swelling } \\
(\%)\end{array}$ \\
\hline $\mathrm{O}$ & 54.17 & 89.00 & 10231.0 & 13.5 & 15.6 \\
\hline $\mathrm{A}$ & 59.10 & 86.47 & 9659.8 & 12.87 & 14.80 \\
\hline $\mathrm{B}$ & 61.97 & 82.28 & 9333.4 & 12.58 & 14.47 \\
\hline $\mathrm{C}$ & 59.55 & 82.29 & 9040.4 & 12.44 & 14.30 \\
\hline $\mathrm{D}$ & 59.26 & 80.74 & 8763.8 & 12.13 & 13.95 \\
\hline $\mathrm{E}$ & 58.11 & 74.62 & 8745.4 & 11.94 & 13.73 \\
\hline $\mathrm{F}$ & 57.62 & 72.56 & 8695.9 & 11.21 & 12.90 \\
\hline $\mathrm{G}$ & 50.74 & 41.99 & 7587.9 & 10.87 & 11.76 \\
\hline $\mathrm{H}$ & 42.45 & 37.07 & 7355.6 & 9.65 & 10.25 \\
\hline
\end{tabular}

According to the results, the decision matrix was formed as shown in Table 3. O, A, B, C, D, E, F, G, and $\mathrm{H}$ symbolize respectively the samples as: the control, $120^{\circ} \mathrm{C}$ for $2 \mathrm{~h}, 120^{\circ} \mathrm{C}$ for $4 \mathrm{~h}, 150{ }^{\circ} \mathrm{C}$ for $2 \mathrm{~h}, 150^{\circ} \mathrm{C}$ for $4 \mathrm{~h}, 180^{\circ} \mathrm{C}$ for $2 \mathrm{~h}, 180^{\circ} \mathrm{C}$ for $4 \mathrm{~h}, 210^{\circ} \mathrm{C}$ for $2 \mathrm{~h}$, and $210^{\circ} \mathrm{C}$ for $4 \mathrm{~h}$. To rank the alternatives, determination of the criteria weights is necessary. Therefore, the calculations first started with entropy method. According to 
the evaluation indexes the standardization of the indexes was calculated and shown by the index below. The weights of indexes were calculated and shown in Table 4 .

$$
R i j=\left[\begin{array}{lllll}
0.10770 & 0.13755 & 0.12883 & 0.09690 & 0.09511 \\
0.11751 & 0.13365 & 0.12164 & 0.10191 & 0.10002 \\
0.12321 & 0.12717 & 0.11753 & 0.10424 & 0.10232 \\
0.11841 & 0.12718 & 0.11384 & 0.10546 & 0.10351 \\
0.11781 & 0.12479 & 0.11036 & 0.10814 & 0.10614 \\
0.11553 & 0.11532 & 0.11013 & 0.10983 & 0.10780 \\
0.11457 & 0.11215 & 0.10950 & 0.11695 & 0.11479 \\
0.10088 & 0.06490 & 0.09555 & 0.12066 & 0.12588 \\
0.08439 & 0.05730 & 0.09262 & 0.13591 & 0.14443
\end{array}\right]
$$

Table 4. Calculated Index Weights

\begin{tabular}{|c|c|c|c|c|c|}
\hline & $\begin{array}{c}\text { Compression } \\
\text { Strength } \\
\left(\mathbf{N} / \mathbf{m m}^{2}\right)\end{array}$ & $\begin{array}{c}\text { Bending } \\
\text { Strength } \\
\left(\mathbf{N} / \mathbf{m m}^{2}\right)\end{array}$ & $\begin{array}{c}\text { Modulus of } \\
\text { Elasticity (MOE) } \\
\left(\mathbf{N} / \mathbf{m m}^{2}\right)\end{array}$ & $\begin{array}{c}\text { Shrinkage } \\
(\%)\end{array}$ & $\begin{array}{c}\text { Swelling } \\
(\%)\end{array}$ \\
\hline $\mathrm{Wj}$ & 0.0927 & 0.6029 & 0.0825 & 0.0833 & 0.1387 \\
\hline
\end{tabular}

According to the calculations, the "bending strength" was the most important criterion by far. Thus, the heat treatment may have significant effect on bending strength of the wood. On the basis of importance levels, other criteria were identified as swelling, compression strength, shrinkage, and modulus of elasticity. In particular, shrinkage and modulus of elasticity criteria have very close weight values. This situation could be interpreted as these two criteria are almost equally important.

After the calculation of weights, TOPSIS method was employed for ranking the test samples. Based on the data at Table 3, the normalized decision matrix is given below.

$$
R i j=\left[\begin{array}{lllll}
0.32144 & 0.40031 & 0.38466 & 0.37707 & 0.38112 \\
0.35072 & 0.38894 & 0.36319 & 0.35853 & 0.36238 \\
0.36773 & 0.37009 & 0.35091 & 0.35049 & 0.35426 \\
0.35340 & 0.37013 & 0.33990 & 0.34647 & 0.35019 \\
0.35163 & 0.36315 & 0.32950 & 0.33787 & 0.34150 \\
0.34480 & 0.33561 & 0.32881 & 0.33266 & 0.33623 \\
0.34194 & 0.32637 & 0.32695 & 0.31242 & 0.31578 \\
0.30109 & 0.18888 & 0.28529 & 0.30281 & 0.28794 \\
0.25188 & 0.16674 & 0.27656 & 0.26883 & 0.25097
\end{array}\right]
$$

The weighted decision matrix was calculated, and the obtained ideal and negative ideal solutions are given below. The distance of every possible solution from the ideal solution and negative ideal solution was calculated. The relative degree of approximation was obtained. The ranking of test samples is according to the relative degree of approximation and is shown in Table 5. 


$$
\begin{aligned}
& V i j=\left[\begin{array}{lllll}
0.02978 & 0.24135 & 0.03172 & 0.03141 & 0.05285 \\
0.03250 & 0.23450 & 0.02995 & 0.02986 & 0.05025 \\
0.03407 & 0.22313 & 0.02894 & 0.02919 & 0.04912 \\
0.03275 & 0.22316 & 0.02803 & 0.02886 & 0.04856 \\
0.03258 & 0.21895 & 0.02717 & 0.02814 & 0.04735 \\
0.03195 & 0.20234 & 0.02712 & 0.02771 & 0.04662 \\
0.03168 & 0.19677 & 0.02696 & 0.02602 & 0.04379 \\
0.02790 & 0.11388 & 0.02353 & 0.02522 & 0.03993 \\
0.02334 & 0.10053 & 0.02281 & 0.02239 & 0.03480
\end{array}\right] \\
& V^{+}=(0.03407,0.24135,0.03172,0.02239,0.03480) \\
& V^{-}=(0.02334,0.10053,0.02281,0.03141,0.05285)
\end{aligned}
$$

Table 5. TOPSIS Results and Evaluation of Ranks

\begin{tabular}{|c|c|c|c|c|c|}
\hline ID & Sample & S+ & S- & $\mathbf{c}^{*}$ & $\begin{array}{c}\text { Evaluation } \\
\text { rank }\end{array}$ \\
\hline $\mathrm{O}$ & Control & 0.02063 & 0.14125 & 0.8725842 & 2 \\
\hline $\mathrm{A}$ & $120^{\circ} \mathrm{C}$ and $2 \mathrm{~h}$ & 0.01863 & 0.1345 & 0.8783331 & 1 \\
\hline $\mathrm{B}$ & $120^{\circ} \mathrm{C}$ and $4 \mathrm{~h}$ & 0.02432 & 0.1233 & 0.8352714 & 4 \\
\hline $\mathrm{C}$ & $150^{\circ} \mathrm{C}$ and $2 \mathrm{~h}$ & 0.02403 & 0.1232 & 0.8367679 & 3 \\
\hline $\mathrm{D}$ & $150^{\circ} \mathrm{C}$ and $4 \mathrm{~h}$ & 0.02675 & 0.11903 & 0.8165139 & 5 \\
\hline $\mathrm{E}$ & $180^{\circ} \mathrm{C}$ and $2 \mathrm{~h}$ & 0.04142 & 0.10252 & 0.7122533 & 6 \\
\hline $\mathrm{F}$ & $180^{\circ} \mathrm{C}$ and 4 $\mathrm{h}$ & 0.04593 & 0.09726 & 0.6792287 & 7 \\
\hline $\mathrm{G}$ & $210^{\circ} \mathrm{C}$ and $\mathrm{h}$ & 0.12802 & 0.02012 & 0.1357924 & 8 \\
\hline $\mathrm{H}$ & $210^{\circ} \mathrm{C}$ and $4 \mathrm{~h}$ & 0.14151 & 0.02017 & 0.1247769 & 9 \\
\hline
\end{tabular}

Notes: S+ represents the distance of the alternative from the ideal solution. S- represents the distance of the alternative from the negative ideal solution. $c^{*}$ represents the success of the alternative.

Compared with the control sample, a slight improvement was recognized in the properties of the sample A, which was subjected to heat treatment at $120^{\circ} \mathrm{C}$ for $2 \mathrm{~h}$. In this case, the heat treatment provides an overall improvement in the properties of the wood. However, when results are examined in detail, especially after $150{ }^{\circ} \mathrm{C}$, the physical and mechanical properties of the wood diminish. If either the duration or the temperature goes up to $4 \mathrm{~h}$ or $180^{\circ} \mathrm{C}$, the decrease becomes drastic. Thus, according to the present work, heat treatment above $150{ }^{\circ} \mathrm{C}$ or $4 \mathrm{~h}$ is not recommended.

The properties of samples that ranked $3^{\text {rd }}(\mathrm{C})$ and $4^{\text {th }}(\mathrm{B})$, and which were subjected to thermal modification at $150{ }^{\circ} \mathrm{C}$ for $2 \mathrm{~h}$ and at $120{ }^{\circ} \mathrm{C}$ for $4 \mathrm{~h}$, are quite similar. In this case, if there are any time constraints, the thermal modification at $150{ }^{\circ} \mathrm{C}$ for $2 \mathrm{~h}$ is recommended. However, if there are any concerns about temperature the application of thermal modification at $120^{\circ} \mathrm{C}$ for $4 \mathrm{~h}$ is recommended.

The main purpose of heat treatment is to improve the physical properties of wood. However, unfortunately this improvement causes the mechanical properties to decrease. The same circumstance exists in the present study. The decrease is acceptable up to a point. In the present work, both 120 and $150{ }^{\circ} \mathrm{C}$ were found as the optimum degrees for the application, and higher temperatures are not recommended. Considering the general situation, regardless of temperature application for $2 \mathrm{~h}$ has given better results. Thus, if 
there is no necessity, longer applications are not recommended.

A comprehensive literature review revealed that many studies have been conducted to reveal the effect of the heat treatment process on the basic performance of wood (Ates et al. 2009; Yang et al. 2016; Zhang et al. 2017). When these studies were examined, it was found out that the variety of experimental design and performance tests were determined by considering the effects that the wood is exposed to in the place of use. When the place of use performance requirements of wood are researched, it is possible to say that basic tests such as bending strength, modulus of elasticity, compression strength, shrinkage, and swelling are generally adequate to evaluate multiple criteria regarding the competence of the place of use. Therefore, based on the literature, the above-mentioned tests were used as the determinants to evaluate the success of heat treatment and identify the optimum parameters.

\section{CONCLUSIONS}

1. Heat treatment affected physical and mechanical properties of the poplar (Populus $a l b a)$ wood. Shrinkage and swelling ratios of the heat-treated wood samples decreased with increasing treatment temperature and duration, and their minimum values were obtained in samples treated at $210{ }^{\circ} \mathrm{C}$ for $4 \mathrm{~h}$.

2. Compression strength, bending strength, and modulus of elasticity (MOE) of the heattreated wood decreased with increasing treatment temperature and duration.

3. The multi-criteria decision-making approach is convenient to be employed in studies that focus on physical and mechanical characteristics of wood.

4. According to Multi-Criteria Decision-Making (MCDM) techniques, thermal modification improves the physical properties of wood up to a point.

5. Bending strength was the determinant that most affected the success of heat treatment. The other determinants were swelling, compression strength, shrinkage, and modulus of elasticity.

6. Based on a multi-criteria analysis, the best results were obtained at $120{ }^{\circ} \mathrm{C}$ for $2 \mathrm{~h}$. However, heat treatment above $150{ }^{\circ} \mathrm{C}$ or $4 \mathrm{~h}$ is not recommended.

7. Increasing the number of MCDM applications on related fields can be useful for a comparative analysis of the results obtained in subsequent heat treatment studies.

\section{ACKNOWLEDGEMENTS}

This research work is a part of the project supported by scientific research foundation (BAP) of Kastamonu University (Project number KU-BAP 01-2016-58).

\section{REFERENCES CITED}

Abidin, M., Rusli, R., and Shariff, A. (2016). "Technique for order performance by similarity to ideal solution (TOPSIS)-entropy methodology for inherent safety design decision making tool," Procedia Engineering 148, 1043-1050. DOI:

10.1016/j.proeng.2016.06.587

Kaymakci \& Bayram (2021). "Heat-treated poplar," BioResources 16(3), 4693-4703. 
Ates, S., Akyildiz, M. H., and Ozdemir, H. (2009). "Effects of heat treatment on Calabrian pine (Pinus brutia ten.) wood," BioResources 4(3), 1032-1043.

Aydin, E. (2019). Physical, Surface, Mechanical, Decay Resistance and Thermal Properties of Oriental Beech Wood Exposed to Heat Treatment, M.Sc. Thesis, Muğla Sitkı Koçman University, Institute of Science and Technology, Department of Woodworking Industrial Engineering, Muğla, Turkey.

Bakhoum, E. S., and Brown, D. C. (2013). "A hybrid approach using AHP-TOPSISentropy methods for sustainable ranking of structural materials," International Journal of Sustainable Engineering 6, 212-224. DOI: 10.1080/19397038.2012.719553

Birler, A. S. (2009). "Endüstriyel Orman Ağaçlandırmaları," Düzce Üniversitesi, Orman Fakültesi Dergisi, Yayın No:4, İstanbul.

Boonstra, M. J. (2008). A Two-Stage Thermal Modification of Wood. Ph.D. Dissertation in Cosupervision Ghent University and Universite Henry Poincare - Nancy 1, 297 p. ISBN 978-90-5989-210-1

Chang, K. H. (2015). "Chapter 2 - Decisions in engineering design,” in: Design Theory and Methods Using CAD/CAE, Academic Press, pp. 39-101.

Durmaz, E., Ucuncu, T., Karamanoglu, M., Kaymakci, A. (2019). "Effects of heat treatment on some characteristics of Scots Pine (Pinus sylvestris L.) wood," BioResources 14(4), 9531-9543. DOI: 10.15376/biores.14.4.9531-9543

Esteves, B., and Pereira, H. (2009). "Wood modification by heat treatment: A review," BioResources 4(1), 370-404.

Esteves, B., Domingos, I., and Pereira, H. (2007). "Improvement of technological quality of eucalypt wood by heat treatment in air at 170-200 ${ }^{\circ} \mathrm{C}$," Forest Product Journal 57 $(1 / 2), 47-52$.

Göker, Y., and Dündar, T. (1999). "Genç Odun Özelliklerinin Odun Kalitesi ve Kullanım Yeri Üzerine Etkileri," İstanbul Üniversitesi Orman Fakültesi Dergisi 49, 31-44.

Gunduz, G., Aydemir, D., and Karakas, G. (2009). "The effects of thermal treatment on the mechanical properties of wild Pear (Pyrus elaeagrifolia Pall.) wood and changes in physical properties," Materials \& Design 30(10), 4391-4395. DOI: 10.1016/j.matdes.2009.04.005

Hillis, W. E. (1984). "High temperature and chemical effects on wood stability," Wood Science and Technology 18(4), 281-293. DOI: 10.1016/j.matdes.2009.04.005

Hwang, C., and Yoon, K. (1981). Multiple Attribute Decision Making Methods and Applications: A State-of-the-art Survey, Springer-Verlag, Berlin.

Kabakci, A., and Kesik, H. I. (2020). "The Effects of water-based insulation paint applied to laminate flooring panels on the thermal conductivity coefficient and adhesion resistance," BioResources 15(3), 6110-6122. DOI: 10.15376/biores.15.3.6110-6122

Kamdem, D. P., Pizzi, A., and Jermannaud, A. (2002). "Durability of heat-treated wood," Holz als Roh-und Werkstoff 60(1), 1-6. DOI: 10.1007/s00107-001-0261-1

Kesik, H. İ., Özkan, O. E., and Öncel, M. (2017). "Characteristics of a protective layer on oil heat-treated scots pine and fir wood," BioResources 12(2), 3067-3075. DOI: 10.15376/biores.12.2.3067-3075

Korkut, D. S., and Guller, B. (2008). "The effects of heat treatment on physical properties and surface roughness of red-bud maple (Acer trautvetteri Medw.) wood," Bioresource Technology 99(8), 2846-2851. DOI: 10.1016/j.biortech.2007.06.043

Kotilainen, R. A., Toivanen, T. J., and Alén, R. J. (2000). "FTIR monitoring of chemical changes in softwood during heating," Journal of Wood Chemistry and Technology 20(3), 307-320. DOI: 10.1080/02773810009349638

Li, X., Wang, K., Liu, L., Xin, J., Yang, H., and Gao, C. (2011). "Application of the 
entropy weight and TOPSIS method in safety evaluation of coal mines," Procedia Engineering 26, 2085-2091. DOI: 10.1016/j.proeng.2011.11.2410

Long, Y., Yang, Y., Lei, X., Tian, Y., and Li, Y. (2019). "Integrated assessment method of emergency plan for sudden water pollution accidents based on improved TOPSIS, Shannon Entropy and a Coordinated Development Degree Model," Sustainability 11, 510. DOI: $10.3390 / \mathrm{su} 11020510$

Mazela, B., Zakrzewski, R., Grzeskowiak, W., Cofta, G., and Bartkowiak, M. (2003). "Preliminary research on the biological resistance of thermally modified wood," in: First European Conference on Wood Modification, Ghent, Belgium.

Militz, H. (2002). "Heat treatment of wood: European processes and their background," in: International Research Group Wood Pre, Section 4-Processes, N ${ }^{\circ}$ IRG/WP 0240241.

Ouyang, L.-Y., Chen, K.-S., Yang, C.-M., and Hsu, C.-H. (2014). "Using a QCACEntropy-TOPSIS approach to measure quality characteristics and rank improvement priorities for all substandard quality characteristics," International Journal of Production Research 52, 3110-3124. DOI: 10.1080/00207543.2013.865092

Percin, O., Peker, H., and Atilgan, A. (2016). "The effect of heat treatment on the physical and mechanical properties of beech (Fagus orientalis Lipsky) wood," Wood Research 61(3), 443-456.

Sayareh, J., and Alizmini, H. R. (2014). "A hybrid decision-making model for selecting container seaport in the Persian Gulf," Asian Journal of Shipping \& Logistics 30(1), 75-95. DOI: 10.1016/j.ajs1.2014.04.004

Shannon, C. E. (1948). "A mathematical theory of communication,” The Bell System Technical Journal 27, 379-423. DOI: 10.1002/j.1538-7305.1948.tb01338.x

Song, M., Zhu, Q., Peng, J., and Santibanez Gonzalez, E. (2017). "Improving the evaluation of cross efficiencies: A method based on Shannon entropy weight," Computers \& Industrial Engineering 112, 99-106. DOI: 10.1016/j.cie.2017.07.023

Syrjänen, T., and Kangas, E. (2000). "Heat-treated timber in Finland," International Research Group Wood Pre, Section 4-Processes, No IRG/WP 00-40158.

TS 2474 (1976). "Wood - Determination of ultimate strength in static bending," Turkish Standards Institution, Ankara, Turkey.

TS 2478 (1976). "Wood - Determination of modulus of elasticity in static bending," Turkish Standards Institution, Ankara, Turkey.

TS 2595 (1977). "Wood - Determination of ultimate stress in compression parallel to grain," Turkish Standards Institution, Ankara, Turkey.

TS 4083 (1983). "Wood - Determination of radial and tangential shrinkage," Turkish Standards Institution, Ankara, Turkey.

TS 4084 (1983). "Wood - Determination of radial and tangential swelling," Turkish Standards Institution, Ankara, Turkey," Turkish Standards Institution, Ankara, Turkey.

Wang, E., Alp, N., Shi, J., Wang, C., Zhang, X., and Chen, H. (2017). "Multi-criteria building energy performance benchmarking through variable clustering-based compromise TOPSIS with objective entropy weighting," Energy 125, 197-210. DOI: 10.1016/j.energy.2017.02.131

Yang, T., Chang, F., Lin, C., and Chang, F. (2016). "Effects of temperature and duration of heat treatment on the physical, surface, and mechanical properties of Japanese cedar wood," BioResources 11(2), 3947-3963. DOI: 10.15376/biores.11.2.3947-3963

Yildiz, S. (2002). "Effects of heat treatment on water repellence and anti-swelling efficiency of beech wood," in: International Research Group Wood Pre, Section 4Processes, N ${ }^{\circ}$ IRG/WP 02-40223. 
Zaman, A., Alen, R., and Kotilainen, R. (2000). "Heat behavior of Pinus sylvestris and Betula pendula at 200-230 ${ }^{\circ}$ C," Wood and Fiber Science 32(2), 138-143.

Zhang, Y. H., Xu, D., Ma, L., Wang, S., and Liu, X. (2017). "Influence of heat treatment on the water uptake behavior of wood," BioResources 12(1), 1697-1705. DOI: 10.15376/biores.12.1.1697-1705

Zhou, K., Lin, Y., Deng, H. Li, J. and Liu, C. (2016). "Prediction of rock burst classification using cloud model with entropy weight," Transactions of Nonferrous Metals Society of China 26, 1995-2002. DOI: 10.1016/S1003-6326(16)64313-3

Article submitted: December 18, 2020; Peer review completed: March 13, 2021; Revised version received and accepted: April 30, 2021; Published: May 4, 2021.

DOI: 10.15376/biores.16.3.4693-4703 